\title{
PENGARUH FASILITAS SEKOLAH TERHADAP HASIL BELAJAR SISWA DI SMK NEGERI 1 PENDOPO PALI
}

\author{
Oleh : Lia Chayani ${ }^{1}$, Januardi ${ }^{2}$ \\ (UNIVERSITAS PGRI PALEMBANG)
}

liachayani3@gmail.com ${ }^{1}$, januardibkl@gmail.com ${ }^{2}$

\begin{abstract}
Abstrak-Metode yang digunakan dalam penelitian ini adalah metode eksperimen atau eksperimental yang merupakan pendekatan penelitian kuantitatif. Hasil dari penelitian ini menunjukan bahwa hasil belajar pada kelas $X$ AK(akuntasi) dari ketiga kelas siswa yang mendapat kriteria sangat baik pada angka 86 - 100 sebanyak 36 orang (83,72\%), nilai dengan kriteria baik pada angka 72 - 89 sebanyak 20 orang (11,63 \%), sedangkan nilai dengan kriteria cukup pada angka 56 - 72 sebanyak 2 orang (4,65\%). Penelitiannya yaitu data hasil penelitian positif. Hasil yang ditetapkan adalah a 0,05. Jika dilihat dari pengujian hipotesis melalui perhitungan uji " $t$ " menunjukkan bahwa beda $t_{\text {tabel }}$ $=2,00>t_{\text {hitung }}=0,22$ dengan besar 1,80\% sedangkan sisanya 98,2\% dipengaruhi faktor lain, maka terima Ha dan Ho ditolak. Oleh karena itu fasilitas sekolah terhadap hasil belajar siswa di SMK N 1 Pendopo PALI dapat dijadikan salah satu cara untuk mempermudah dalam proses pembelajaran pada mata pelajaran apapun dan semua jurusan yang ada di sekolah tersebut.
\end{abstract}

Kata Kunci : Fasilitas Sekolah, Hasil Belajar

Abstract-The method used in this study is an experimental or experimental method which is a quantitative research approach..The results of this study indicate that the learning outcomes in class X AK (accounting) of the three classes of students who received very good criteria at number 86-100 were 36 people $(83.72 \%)$, the value with good criteria at numbers $72-89$ were 20 people (11.63\%), while the scores with sufficient criteria in the numbers $56-72$ are as many as 2 people (4.65\%). His research is positive research result data. The result set is $\alpha 0.05$. If seen from testing the hypothesis through the calculation of the test " $t$ " shows that the difference $t$ table $=2.00>t \_$count $=0.22$ with a magnitude of $1.80 \%$ while the remaining $98.2 \%$ is influenced by other factors, then accept $\mathrm{Ha}$ and $\mathrm{Ho}$ is rejected. Therefore, school facilities for student learning outcomes at SMK N 1 Pendopo PALI can be used as a way to facilitate the learning process in any subject and all departments in the school.

Keywords : School Facility, Learning Outcomes.

PENDAHULUAN

Pendidikan adalah ilmu pengetahuan yang diberikan oleh seseorang guru untuk mewujudkan psesrta didik yang cerdas dan meningkatkan suasana belajar dan proses pembelajaran agar peserta didik secara aktif mengembangkan 
potensi dirinya untuk memiliki kekuatan spiritual keagamaan, pengendalian diri, akhlak mulia, serta keterampilan yang diperlukan dirinya dan masyarakatnya. Pada dasarnya setiap anak memiliki hak untuk memperoleh pendidikan. Pengukuran prestasi belajar dapat dilihat dari nilai ulangan harian (UH), ulangan tengah semester (UTS), ataupun ulangan akhir semester (UAS). Prestasi belajar siswa dipengaruhi oleh dua faktor yaitu dari subjek belajar, antara lain bakat, minat, aktivitas, belajar, motivasi belajar, imtelegensi yang dimiliki atau kecerdasan yang dimiliiki, dan faktor dari luar siswa yaitu lingkungan, cara belajar, kurikulum, program pengajaran dan fasilitas belajar yang memadai.

Fasilitas adalah segala sesuatu yang dapat memudahkan dan memperlancarpelaksanaan suatu usaha dapat berupa benda-benda maupun uang. Dalam prosesbelajar mengajar di sekolah, fasilitas atau sarana dan prasarana merupakan salah satu bagian yang paling penting, karena dapat membantu kelancaran dan kenyamanan dalam proses belajar di sekolah. Prasarana meliputi gedung sekolah, ruang belajar, lapangan olahraga, ruang ibadah, ruang kesenian dan peralatan olah raga. Sarana pembelajaran meliputi buku pelajaran, buku bacaan, alat dan fasilitas laboratorium sekolah dan berbagai media pembelajaran yang lain, karena jika tidak adanya fasilitas yang disediakan maka sangat sulit bagi siswa untuk melakukan kegiatan belajar.Hasil belajar merupakan belajar memegang peranan penting bagi perkembangan, kebiasaan, sikap, keyakinan, tujuan, kepribadian dan bahkan persepsi manusia.

$$
\text { Belajar adalah usaha }
$$
penguasaan materi ilmu pengetahuan yang merupakan sebagian kegiatan menuju terbentuknya kepribadian seutuhnya. Menurut Oemar Hamalik (2011 : 30-33). Hasil belajar ialah terjadinya perubahan tingkah laku pada orang tersebut, misalnya dari tidak tahu menjadi tahu, dan dari tidak mengerti menjadi mengerti. Melalui proses belajar manusia dapat mengembangkan potensi yang dibawanya sejak lahir. Pendidikan formal selalu diikuti pengukuran dan penilaian, demikian juga dalam proses kegiatan belajar mengajar, dengan mengetahui hasil belajar dapat diketahui kedudukan siswa yang pandai, sedang atau lambat. Laporan hasil belajar yang diperoleh siswa diserahkan dalam periode tertentu yaitu dalam bentuk Buku Rapor. Jadi hasil belajar merupakan hasil yang dicapai setelah seseorang mengadakan sesuatu kegiatan belajar yang terbentuk dalam suatu nilai hasil belajar yang diberikan oleh Guru. Usaha untuk mencapai suatu hasil belajar dari proses belajar mengajar seseorang siswa dipengaruhi oleh faktor internal dan eksternal. 
Faktor internal yang timbul dari dalam diri siswa itu sendiri, digolongkan menjadi dua yaitu: faktor jasmaniah dan faktor psikologis. perubahan tingkah laku walaupun tidak semua perubahan tingkah laku mempengaruhi hasil belajar, akan tetapi aktivitas belajar umumnya disertai perubahan tingkah laku. Perubahan tingkah laku pada kebanyakan hal merupakan sesuatu perubahan yang diam, Perubahan tingkah laku yang dimaksudkan sebagai hasil belajar tersebut dapat diamati. Menurut Annurrahman (2012: 37).

Fasilitas dan Hasil belajar siswa sangat berhubungan satu sama lain terutama disekolah, siswa akan bertambah giat dalam belajar jika fasilitas yang ada sangat lengkap dan bisa membantu siswa dalam kegiatan belajar, maka akan dapat juga membantu guru dalam melaksanakan kegiatan pembelajaran. Menurut Meita Satri (2017:445), mengartikan bahwa fasilitas balajar adalah salah satu faktor dari luar yang dapat mempengaruhi hasil belajar. Sarana untuk melancarkan pelaksanaan fungsi atau kemudahan. Artinya fasilitas belajar mempunyai peranan penting dalam mendukung kegiatan belajar siswa karena fasilitas belajar merupakan sarana dan prasarana yang dapat menunjang kegiatan belajar siswa disekolah. Terutama fasilitas seperti perpustakaan ini sangat dibutuhkan untuk siswa , untuk mencari bahan belajar seperti buku-buku yang diperlukan, tetapi harus ada bimbingan dan arahan dari seorang guru agar siswa tersebut mau memfaatkan fasilitas yang ada disekolah, selain untuk meningkatkan ilmu pengetahuan dan hasil belajar siswa. fasilitas disekolah juga akan membuat siswa berprestasi dalam belajar. Tetapi jika seorang guru tidak ada arahan atau membimbing siswa untuk menggunakan fasilitas yang sudah ada disekolah maka akan percuma fasilitas sekolah yang sudah disediakan.

Berdasarkan observasi yang telah dilakukan di SMK N 1 Pendopo Pali bahwa fasilitas sekolah yang merupakan sarana dan prasarana yang digunakan pihak sekolah dalam mendukung proses pembelajaran, sudah sangat baik dan fasilitas yang disediakan sangat memadai untuk digunakan saat belajar maupun diluar jam pelajaran.

Fasilitas yang dimulai dari ruangan belajar yang nyaman,bersih,rapi dan buku-buku pelajaran yang disediakan sudah sangat lengkap untuk digunakan saat belajar begitpun sarana dan prasarana tersebut dari seluruh fasilitas yang ada yaitu salah satunya perpustakaan sekolah. Perpustakaan sekolah yang dimiliki pada saat ini sudah lumayan baik dan memenuhi persyaratan. Akan tetapi kebanyakan siswa yang kurang berminat untuk menggunakan fasilitas yang sudah disediakan 
disekolah. Maka dari itu hasil belajar siswa sering tidak sesuai diakhir ujian sekolah, karena siswa kurang memanfaatkan fasilitas yang sudah disediakan disekolah.

Berdasarkan permasalahan yang didapat dari penjelasan diatas, maka peneliti bermaksud untuk melakukan penelitian di SMK Negeri 1 untuk mengetahui Pengaruh fasilitas sekolah terhadap hasil belajar siswa di kelas X Akuntansi di SMK Negeri 1 Pendopo PALI. Hal ini untuk melihat seberapa besarnya kemauan siswa dalam menggunakan fasilitas yang sudah disediakan disekolah, jika sudah maksimal siswa menggunakannya maka hasil beljar siswa pasti akan meningkat.

Berdasarkan uraian latar belakang di atas, maka peneliti mengadakan penelitian yang berjudul

"Pengaruh Fasilitas Sekolah Terhadap Hasil Belajar Siswa di SMK Negeri 1 Pendopo Pali”.

\section{METODE PENELITIAN}

Sugiyono

(2016:02)

mengatakan bahwa "metode penelitian pada dasarnya merupakan cara ilmiah untuk mendapatkan data dengan tujuan dan kegunaan tertentu". Sehubungan dengan masalah yang akan diteliti maka peneliti akan menggunakan metode eksperimen atau eksperimental yang merupakan pendekatan penelitian kuantitatif. Metode kuantitatif digunakan untuk meneliti pada populasi atau sampel tertentu.
Sugiyono (2016:14) teknik pengambilan sampel pada umumnya dilakukan secara pengumpulan data menggunakan instrumen penelitian, analisis data bersifat kuantitatif/statistik dengan tujuan untuk menguji hipotesis yang ditetapkan.

Menurut

Arikunto (2014:174), "Sampel adalah sebagian atau wakil populasi yang diteliti". Untuk menentukan jumlah sampel dalam penelitian ini peneliti menggunakan Sampling Purposive. Menurut Arikunto (2014:183), Sampling Purposive adalah bertujuan dilakukan dengan cara mengambil subjek bukan didasarkan atas strata, random atau daerah tetapi didasarkan atas adanya tujuan tertentu".

Penelitian ini dilaksanakan di SMK Negeri 1 yang beralamat di Jl.Komplek handayani, Kel. Handayani, Kec. Talang Ubi Pali. Penelitian ini dilakukan di kelas $\mathrm{X}$ jurusan Akuntansi. Pada penelitian ini, teknik pengumpulan data yang digunakan yaitu :

1. Dokumentasi

Dalam penelitian ini dokumentasi yang didapat yaitu dari hasil belajar siswa diambil pada saat siswa melaksanakan ulangan harian, nilai yang diperoleh siswa itu sesuai dengan kemampuan siswa saat mereka menjawab soalsoal dan pertanyaan yang diberikan oleh guru mata pelajaran.

2. Kuesioner (Angket) 
Kuesioner merupakan teknik pengumpulan data yang efesien bila peniliti tahu dengan pasti variabel yang akan diukur dan tahu apa yang bisa diharapkan dari responden. Selain itu, konsioner juga cocok digunakan bila jumlah responden cukup besar dan terbesar di wilayah yang luas dan apat berupa pertanyaan/pertanyaan tertutup atau terbuka, dapat diberikan kepada responden secara langsung atau dikirim melalui pos, atau internet.

Teknik analisis yang digunakan dalam penelitian ini menggunakan analisis data angket sedangkan uji intrumen yang digunakan yaitu: uji normalitas data, uji homogenitas data, dan uji hipotesis dengan persamaan regresi $t$ hitung. Dan analisis regresi linier sederhana untuk membantu mencari pngaruh fasilitas sekolah terhadap hasil belajar siswa.

Tabel 1. Kisi-kisi dijadikan Dasar Sebagai Pembuatan Kuesioner (Angket)

\begin{tabular}{|c|c|c|}
\hline Variabel & Indikator & Kisi-kisi \\
\hline $\begin{array}{l}\text { Pelayanan } \\
\text { fasilitas } \\
\text { sekolah (X) }\end{array}$ & $\begin{array}{c}\text { 1. Fasilitas } \\
\text { Sekolah }\end{array}$ & $\begin{array}{l}\text { 1. Gedung Sekolah } \\
\text { 2. Perlengkapan belajar } \\
\text { 3. Ruang kelas } \\
\text { 4. Ruang praktek } \\
\text { (Lab sesuai jurusan) }\end{array}$ \\
\hline & $\begin{array}{l}\text { 2. Fasilitas } \\
\text { Perpustakaan }\end{array}$ & $\begin{array}{l}\text { 1. Sumber informasi } \\
\text { 2. Memberikan petunjuk } \\
\text { 3. Kemampuan petugas } \\
\text { 4. Pemberian bantuan secara kontinu } \\
\text { 5. Pembuatan bantuan kartu anggota } \\
\text { 6. Koleksi\&penataan buku } \\
\text { 7. Kelengkapan koleksi. }\end{array}$ \\
\hline
\end{tabular}

Sumber: Penelitian

\section{HASIL DAN PEMBAHASAN}

\section{Hasil Penelitian}

\section{Deskripsi Pelakasanaan Penelitian}

Penelitian ini dilaksanakan di SMK Negeri 1 yang beralamat di Jl.Komplek Handayani, Kel.Handayani, Kec.Talang Ubi Pali. Kegiatan penelitian ini dilaksanakan bulan Agustus pada semester Ganjil tahun pelajaran 2019. Dengan jumlah sampel 60 yang terdiri dari kelas $\mathrm{X}$ AK 1 yang berjumlah 20 siswa, kelas $\mathrm{X}$ AK 2 dengan 20 siswa dan kelas $\mathrm{X}$ AK 3 yang berjumlah 20 siswa. Penelitian ini dilakukan 3 kali pertemuan untuk masing-masing pada kelas sampel dan 1 kali pertemuan dilakukan untuk tes. Kegiatan belajar mengajar 
dilaksanakan di kelas pada hari Selasa 16 Juli - 14 Agustus 2019.

\section{Deskripsi Hasil Angket \\ Pengelolaan Kelas}

Data hasil tas angket yaitu siswa yang diberi angket untuk mengetahui pangaruh pengolaan kelas terhadap hasil belajar pada mata pelajaran Akuntansi di SMK Negeri 1 Pendopo PALI. Angket Tersebut terdiri dari 30 pertanyaan yakni pertanyaan tentang pengolaan kelas. Pertanyaan bernilai 4 jika Jawaban sebaran angketnya sangat setujuh, bernilai 3 jika jawaban angketnya setujuh, dan bernilai 2 jika jawaban angketnya tidak setujuh. Bernilai 1 jika jawaban angketnya tidak pernah dengan menganalisis skor-skor dari penyebaran angket siswa tersebut maka dapet diolah dengan mentabulasikan data tersebut yang dapat diuraikan sebagai berikut:

Dari data diatas dapat diketahui rata-rata pengelolaan kelas pada siswa pelajaran akuntansi di SMK Negeri 1 Pendopo PALI sebesar 79,42 .

Tabel 2. Distribusi Hasil Belajar Siswa

\begin{tabular}{|c|c|c|c|c|}
\hline No & $\begin{array}{c}\text { Interval } \\
\text { Penilaian }\end{array}$ & Frekuensi & Presentasi & Keterangan \\
\hline 1 & $86-100$ & 36 & $83,72 \%$ & Sangat Baik \\
\hline 2 & $72-89$ & 20 & $11,63 \%$ & Baik \\
\hline 3 & $56-72$ & 8 & $4,65 \%$ & Cukup \\
\hline 4 & $40-55$ & 2 & - & Kurang Baik \\
\hline 5 & $\leq 40$ & - & - & Sangat Kuarng \\
\hline \multicolumn{2}{|c|}{ Jumlah } & 60 & $100 \%$ & \\
\hline Rata-rata & \multicolumn{3}{|c|}{$85,44 \%$} & \\
\hline
\end{tabular}

Sumber : diolah dari hasil penelitian

Data hasil belajar diperoleh dari nilai ulangan harian mata pelajaran akuntansi siswa kelas $\mathrm{X}$ AK di SMK Negeri 1 Pendopo PALI, dengan hasil tersebut kemudian dilakukan pengkatagorian hasil belajar berdasarkan Kriterian Ketuntasan Minimal(KKM) yang sudah ditetapkan sebesar 75. Maka dapat dikatagorikan siswa yang sangat baik itu sebanyak 36 siswa dengan presentasi $(83,72 \%)$, siswa dengan katagori baik itu sebanyak 20 siswa dengan presentasi(11,63\%), dan dengan katagori cukup tu 8 siswa dengan presentasi $(4,65 \%)$ sedangkn siswa yang berkatagori kurang baik itu hanya 2 orang siswa.

Berdasarkan tabel diatas, maka dapat dilihat bahwa setiap kelas yang peneliti lakukan penelitian hasil belajar terbesar pada kategori "sangat baik" dan pada sebagian besar berkatagori "Baik" dan ada beberapa 
orang juga yang berkatagori "Cukup". Rata - rata nilai hasil belajar kelas $\mathrm{X}$ memperoleh nilai 80 yang berada pada katagori "Baik" dan rata-rata 70 dengan katagori "Cukup".

Dari tabel diatas terlihat bahwa terdapat perbedaan hasil belajar siswa kelas $\mathrm{X}$ sebagagian besar berada pada katagori "Baik" sedangkan yang berkatagori "Cukup" dari rata-rata siswa juga berbeda yaitu pada Ketiga kelas yang sudah saya teliti sebesar 80 yang berada pada katagori "Baik" sedangkan sisanya yaitu 70 berkatagori "Cukup" , perhitungan tabel dan data hasil belajar siswa dapat dilihat pada lampiran.

Jika dapat disimpulkan siswasiswa kelas X AK (akuntansi) yang diajar dengan menggunakan fasilitas yang disediakan disekolah, terlihat mendapatkan hasil belajar pada katagori "Baik" dibandingkan hanya menggunakan buku saja.

Dapat dilihat dari diagram berikut ini.

\begin{tabular}{|c|c|}
\hline $56-75$ & $40-55$ \\
Cukup & Kurang \\
$1,4 \%$ & Baik... \\
$72-89$ & $86-100$ \\
baik & sangat \\
$3,2 \%$ & baik... \\
& \\
& \\
\end{tabular}

Gambar 1 Distribusi Hasil Belajar

\section{Pengujian Hipotesis}

Pada pengujian hipotesis yang dihitung dengan menggunakan hasil persamaan regresi yaitu $\bar{y}=74,8+$
75,11 $D$ diperoleh hasil pada pengujian hipotesis uji " $\mathrm{t}$ " menunjukkan bahwa beda $t_{\text {hitung }}$ $2,75>t_{\text {tabel }} 0,011$. Sehingga berdasarkan kriteria Ho ditolak $\mathrm{Ha}$ diterima. Bearti ada pengaruh fasilitas sekolah terhadap hasil belajar di SMK N 1 Pendopo PALI, dimana besar pengaruhnya adalah $13,48 \%$ sedangkan sisanya (100$13,48)=86,52 \%$ dipengaruhi oleh faktor lain yang tidak dijelaskan dalam penelitian ini.

\section{Pembahasan}

Berdasarkan hasil penelitian yang didapat menunjukan bahwa hasil belajar pada kelas $\mathrm{X}$ AK(akuntasi) dari ketiga kelas siswa yang mendapat kriteria sangat baik pada angka 86 - 100 sebanyak 36 orang $(83,72 \%)$, nilai dengan kriteria baik pada angka 72 - 89 sebanyak 20 orang $(11,63 \%)$, sedangkan nilai dengan kriteria cukup pada angka 56 - 72 sebanyak 2 orang (4,65\%). Penelitiannya yaitu data hasil penelitian positif. Taraf signifikasi yang ditetapkan adalah $\alpha$ 0,05. Dengan $\mathrm{T}$ tabel 2,00 berdasarkan pengelolaan data dengan uji-t $\mathrm{T}$ hitung 0,22 , maka Ho ditolak HI diterima.

Penelitian ini juga sejalan dengan penelitian yang dilakukan Taufiq Arinoto (2014) yang menunjukkan adanya " Pengaruh Fasilititas Solah Dan Lingkungan Sekolah Terhadap Kepuasan Siswa Melalui Mutu Layanan Di SMA 
Swasta Sekecamatan Pedurungan Kota Semarang. Hasil penelitian yang direkomendasikan adalah fasilitas sekolah berpengaruh langsung terhadap kepuasan siswa dengan nilai koefisien jalurnya sebesar 0,331 .

Dari hasil penelitian yang dilakukan di MAN 1 Mediunyaitu untuk mengetahui pengeruh fasilitas terhadap hasil belajar akuntansi penelitian ini dilakukan 2 kelas terdiri dari XI IPS berjumlah 30 siswa dan XII IPS 30 siswa. Hasil penelitian menunjukan bahwa fasilitas sekolah maupun Lingkungan sosial secara parsial berpengaruh signifikan terhadap hasil belajar siswa kelas XI dan XII IPS 1 MAN 1 Madiun. Hasil uraian diatas membuktikan bahwa hasil belajar siswa yang menggunakan fasilitas sekolah meningkat jika dibandingkan dengan hanya beberapa buku disekolah. Oleh karena itu , fasilitas sekolah dapat dijadikan salah satu alternatif dalam proses belajar pada mata pelajaran akuntansi. Hal tersebut terbukti bahwa siswa yang diajarkan dengan menggunakan fasilitas sekolah memperoleh hasil belajar lebih tinggi dibandingkan kelas yang diajarkan hanya dengan penjelasan guru.

Pada pengujian hipotesis yang dihitung dengan menggunakan hasil persamaan regresi yaitu $\bar{y}=74,8+$ $75,11 \quad D$ diperoleh hasil pada pengujian hipotesis uji " $\mathrm{t}$ " menunjukkan bahwa beda $t_{\text {hitung }}$
2,75 $>t_{\text {tabel }} 0,011$ Sehingga berdasarkan kriteria Ho ditolak $\mathrm{Ha}$ diterima. Bearti ada pengaruh fasilitas sekolah terhadap hasil belajar di SMK N 1 Pendopo PALI, dimana besar pengaruhnya adalah $13,48 \%$ sedangkan sisanya (100$13,48)=86,52 \%$ dipengaruhi oleh faktor lain yang tidak dijelaskan dalam penelitian ini.

Dari uraian diatas membuktikan bahwa hasil belajar yang menggunakan fasilitas yang ada disekolah meningkat jika dibandingkan dengan hanya satu buku pelajaran yang dipakai. Oleh karena itu, fasilitas sekolah juga dapat dijadikan salah satu alternatif dalam prosese pembelajaran pada mata akuntansi. Hal tersebut terbukti bahwa siswa kelas $\mathrm{X}$ yang diajarkan dengan menggunakan fasilitas yang ada disekolah memperoleh hasil belajar lebih tinggi dibandingkan belajar dengan hanya fokus satu buku.

\section{KESIMPULAN DAN SARAN}

Kesimpulan

Berdasarkan hasil analisis data mengenai pengaruh fasilitas sekolah terhadap hasil belajar siswa di SMK N 1 Pendopo PALI disimpulkan sebagai berikut :

1. Berdasarkan dari hasil penelitian pengaruh fasilitas sekolah itu berpengaruh sangat kecil yaitu bernilai $1,80 \%$ dan berdasarkan distribusi hasil belajar ternyata pada ke pada kelas $\mathrm{X}$ AK 
(akuntasi) dari ketiga kelas siswa yang mendapat kriteria sangat baik pada angka $86-100$ sebanyak 36 orang $(83,72 \%)$, nilai dengan kriteria baik pada angka $72-89$ sebanyak 20 orang $(11,63 \%)$, sedangkan nilai dengan kriteria cukup pada angka 56 - 72 sebanyak 2 orang $(4,65 \%)$. Jadi dapat disimpulkan dari perbandingan nilai dari kelas yang satu kekelas yang lainnya terdapat perbedaan. Maka penelitian dapat menyimpulkan bahwa hasil belajar siswa pada setiap kelas berbeda sangat baik itu terdapat dikelas X AK 1.

2. Berdasarkan hasil persamaan regresi yaitu $\bar{Y}=75,46+1,64=$ $77,85 \mathrm{D}$ diperoleh hasilada pengujian hipotesis uji " $\mathrm{t}$ " menunjukkan bahwa $t_{\text {hitung }}$ $2,00>t_{\text {tabel }} 0,22$, sehingga berdasarkan kritiria Ho ditolak dan $\mathrm{Ha}$ diterima. Bearti ada pengaruh fasilitas sekolah terhadap hasil belajar siswa di SMK N 1 Pendopo PALI. Dimana besar pengaruhnya adalah $1,80 \quad \%$ sedangkan sisanya $(100-2,62)=98,2 \%$ dipengaruhi oleh faktor lain yang tidak dijelaskan dalam penelitian ini.

\section{Saran}

Berdasarkan hasil penelitian yang telah dilakukan, maka peneliti memberi saran berikut ini :
1. Bagi sekolah, untuk mengingatkan kualitas pembelajaran akuntansi hendaknya sekolah memberikan pelatihan keterampilan untuk mengelolah data keuangan agar bisa menjelaskan kepada temannya yang kurang memahami akan pelajaran tersebut agar dapat mudah belajar dan memahami tentang pelajaran akuntansi serta dengan adanya fasilitas yang disediakan disekolah dapat mengembangkan, meningkatkan kualitas dan keinginan siswa dalam dunia pendidikan.

2. Bagi guru, khususnya mata pelajaran akuntansi fasilitas sekolah yang disediakan dapat digunakan secara alternatif dan digunakan dalam kegiatan belajar mengajar sehingga diharapkan dapat meningkatkan hasil belajar siswa.

3. Bagi siswa, dengan menggunakan fasilitas yang disediakan disekolah dapat digunakan siswa belajar agar menarik dan merangsang siswa untuk aktif saat belajar , sehingga dapat meningkatkan hasil belajar.

4. Bagi kalangan akademik, dapat memberikan masukan dan informasi serta sumber bacaan bagi peneliti yang akan datang.

\section{DAFTAR PUSTAKA}

Arikunto. 2013. Dasar-Dasar Evaluasi Pendidikan. Jakarta: Bumi Aksara. 


\section{Prosedur}

Penelitian. Jakarta: PT.Rineka Cipta.

Aunurrahaman.2012. Belajar dan Pembelajaran. Bandung: Alfabeta.

Hamalik, Oemar. 2011. "Proses Belajar Mengajar", Jakarta: PT.Bumi Aksara

Satri, Meita. 2016. "Pengaruh Fasilitas Belajar, Gaya Belajar dan Minat Belajar Terhadap Hasil Belajar Mata Pelajaran Ekonomi Siswa Kelas X IIS SMA Negeri 1 Seyegan”. Fakultas Ekonomi, Volume 6 Nomor 52016 (1-8) (online) Universitas Negeri Yogyakarta. Email:

meythasathree@gmail.com (diakses 11 juli 2019, 15:05).

Sugiyono. 2016. Metode Penelitian. Bandung: Alfabeta.

Sianipar, Edwar. 2017. Statistik Analisis Regresi \& Korelasi. Indonesia-Palembang. 